\title{
Modelling of hydrodynamic and solute transport with consideration of the release of low-level radioactive substances
}

\author{
Roman Winter ${ }^{1}$, Bernd Flemisch ${ }^{1}$, Holger Class $^{1}$, and Rainer Merk ${ }^{2}$ \\ ${ }^{1}$ Institut für Wasser- und Umweltsystemmodellierung, University of Stuttgart, 70569 Stuttgart, Germany \\ ${ }^{2}$ BfS Federal Office for Radiation Protection, 38201 Salzgitter, Germany
}

Correspondence: Roman Winter (roman.winter@iws.uni-stuttgart.de)

Published: 10 November 2021

\begin{abstract}
When nuclear power plants are dismantled, only a small portion is heavily contaminated with radioactivity and must be stored in a repository. The remaining material, mainly concrete rubble (construction waste), is decontaminated if necessary and can be stored in conventional surface landfills after clearance. The focus of this work is on the modelling of such landfills and the radioactive substances during raining events. The influence of the heterogeneous nature of the construction rubble should also be investigated. The simulation environment $\mathrm{DuMu}^{\mathrm{x}}$, mainly developed by our institute, is used to compare different modelling approaches. It follows a previous work by Merk (2012).

The research work is supported and accompanied by the Federal Office for Radiation Protection (BfS). Parts of the research initiatives of the BfS in the area of clearance of materials with negligible radioactivity are also presented.
\end{abstract}

Kurzfassung. Beim Abbruch von Kernkraftwerken ist nur ein sehr geringer Teil stark radioaktiv kontaminiert und muss in einem Endlager gelagert werden. Der Rest, hauptsächlich Betonbruchmaterial (Bauschutt), wird - falls nötig - dekontaminiert und kann nach der Freigabe auf konventionellen Oberflächendeponien gelagert werden. Der Schwerpunkt dieser Arbeit liegt auf der Modellierung dieser Deponien und der radioaktiven Stoffe bei Regenereignissen. Es soll auch der Einfluss der heterogenen Beschaffenheit des Bauschutts untersucht werden. Dabei wird die hauptsächlich von unserem Institut entwickelte Simulationsumgebung $\mathrm{DuMu}^{\mathrm{x}}$ verwendet, um unterschiedliche Modellierungsansätze zu vergleichen. Sie lehnt sich dabei an vorherige Arbeiten von Merk (2012) an.

Diese Forschungsarbeit wird vom Bundesamt für Strahlenschutz (BfS) gefördert und begleitet. Teile der Forschungsaktivitäten des BfS im Bereich Freigabe geringfügig radioaktiver Stoffe werden auch präsentiert.

\section{References}

Merk, R.: Numerical modeling of the radionuclide water pathway with HYDRUS and comparison with the IAEA model of SR 44, J. Environ. Radioactiv., 105, 60-69, https://doi.org/10.1016/j.jenvrad.2011.10.014, 2012. 